\title{
EDUCATION MOVEMENT OF SHIA GROUP IN CONTEMPORARY INDONESIA
}

\author{
Dahlia Lubis \\ Universitas Islam Negeri Sumatera Utara \\ Jl. Willem Iskandar Pasar V Medan Estate, Medan, Sumatera Utara, Indonesia, 20371 \\ e-mail: dahlialubis@uinsu.ac.id \\ Syarifah Rahmah* \\ Institut Agama Islam Negeri Lhokseumawe \\ Jl. Medan-Banda Aceh, Alue Awe, Muara Dua, Lhokseumawe, Aceh, Indonesia, 24352 \\ e-mail: syarifahrahmah@iainlhokseumawe.ac.id
}

\begin{abstract}
The aim of this research is to look at the Shia educational movement in Indonesia as it develops its philosophy. Document study activities, observation, and interviews were used to gather data. Two findings were offered in this study. The first is marriage, which is a technique for expanding the number of Shiites in Indonesia by allowing a husband and wife to establish an Islamic family structure based on Shia beliefs. In this setting, the family serves as the primary educational institution in Indonesia for theyoung Shia generation. The second, internalization of information, attitudes, and abilities, takes place in activities created by Islamic organizations and foundations founded by Shia groups in Indonesia. The many organizations and foundations involved in education and religion have formed a venue for Shia community education in introducing and propagating their schools of thought.
\end{abstract}

Keywords: educational institutions, shia, minority groups

* Corresponding Author 


\section{Introduction}

At both the international and national levels, the Shia movement remains a major source of worry. This is due to considerable differences of opinion in Islam about Shï ite philosophy. In Indonesia, Shi' ism doctrine was propagated through educated circles, and the phenomena of major cities and educated people who obtained Islamic education in Iran was still prominent. ${ }^{1}$ The Indonesian Ulema Council (MUI), which is sponsored by a majority Sunni Moslem organization, issues heretical fatwas for Shia teachings based on their understanding of religion in the suggestions and prohibitions in ritual worship. ${ }^{2}$

Despite harassment and intimidation from intolerant parties in Indonesia, Shia groups continue to expand and increase their numbers of adherents. Various rejections and persecutions continue to come in, but this does not deter fans of the genre from developing their flow. ${ }^{3}$ Shiite groups make advancement for the sake of progress, which is fueled by the birth and growth of diverse Shia educational institutions, both formal and informal. This flow is not a new one in Indonesia; it has existed and flourished since the arrival of Islam several centuries ago. However, with the collapse of President Soeharto's rule, which marked the beginning of Indonesia's reform era, minority groups such as the Shia began to flourish significantly. Their major technique for establishing, promoting, and strengthening Shia schools in Indonesia is via education.

Education is a crucial component of Shia school expansion in Indonesia. Education, in Dewey's words, is the process of assisting learning in order to disseminate information, skills, values, beliefs, and habits, with educators guiding students to learn for themselves. ${ }^{4}$ Shiite knowledge, beliefs, and customs can, of course, be handed on through education from the older 
generation (educators) to the younger age (students). According to some experts, education is a vehicle for instilling information, attitudes, and abilitie.

Education techniques used by the Shia movement include small organized groups, non-formal organizations, and educational institutions. At the level of the Shia family community, Shia youth community, and Shia schools/foundations, dissemination through Shia associated organizations and foundations emerges and flourishes. Shia ideology is implanted as early as feasible, and it can happen through marriages to non-Shia populations. Informal, non-formal, and formal educational institutions can all host educational and learning events. Shia ideology may be passed down to students from these three educational institutions, ensuring that they have the information, attitudes, and skills they will need in the future. As a result, the importance of education in the Shia movement is linked to the evolution of Shiite ideology in Indonesia.

The Shia education movement in Indonesia has received little attention from Indonesian Islamist researchers. Among them are Kholilul Rahman, ${ }^{5}$ M. Andi Isya', ${ }^{6}$ and Muhammad Asrori. ${ }^{7}$ Other researchers focus on the Shia and Sunni conflicts in Indonesia such as Muhammad Iqbal and Ja'far, ${ }^{8}$ A. Rokhmad, ${ }^{9}$ D. Sofjan, ${ }^{10} \mathrm{~W}$. Iryana, ${ }^{11}$ Rachmah Ida \& Muhammad Saud, ${ }^{12}$ Ahmad Zainal Abidin, et al., ${ }^{13}$ and Ahmad Saefudin and Fathur Rohman. ${ }^{14}$ In general, this study differs significantly from the findings of previous researchers. The educational movement of Shia groups in modern Indonesia will be revealed in this study. According to this report, Shia organizations in Indonesia use educational institutions to disseminate their schools of thought throughout the archipelago. 


\section{Methodology}

The influence of Shia educational institutions in the development of Shia ideology in Indonesia will be investigated in this study. This research will focus on how minority Shiite communities launched the creation of educational institutions and their involvement in the proliferation of Shia schools in Indonesia. This research is the outcome of a qualitative study that looked into Shia educational establishments in Indonesia. The data was gathered by document examination and observation, and it was analyzed using the Mile and Huberman data analysis model, in which the data was reduced, presented, and conclusions were produced. ${ }^{15}$

\section{Results and Discussion}

\section{History and Current Conditions of Shia in Indonesia}

Shia is a phrase that refers to people who follow 'Ali and Ahlul Bait. The Imamiyah Shia, Isma'iliyah Shia, and Zaidiyah Shia sects arose and evolved throughout the early stages of Islam's expansion in the Arabian Peninsula, and eventually separated into different groupings. ${ }^{16}$ In the Islamic world, Shia organizations are a minority. Shia groups, on the other hand, are the majority in some countries, such as Iran and Iraq, and have considerable followings in Lebanon, Pakistan, India, and Bahrain. ${ }^{17}$

From the Fathimiyah dynasty through the Buwaihi dynasty to the Safavid dynasty, Shi' ites' survival and resurrection in the globe has been linked to their capacity to capture power. Iran's Islamic revolution, led by Imam Khomeini, a popular Shia cleric in the modern era, shocked the world until Shia Moslems in Iran finally succeeded in forming the Islamic Republic of Iran, a modern state based on the concept of wilayat al-faqih, which cannot be separated from Shia Imamiyah doctrine. ${ }^{18}$ 
Shiite groups grew fast in the contemporary age after the events of the Islamic Revolution of Iran in 1979 in Iran, when Imam Khomeini was a prominent figure in the effort to overthrow the Iranian Shah from his throne. ${ }^{19}$ The victory of Khomeini against Shah Pahlavi was a Shia victory all over the world. Shiites make up nearly all of Iran's population. They follow the Shia Imamiyah or Shia Itsna 'Asyariah schools, which are both quite popular in Iran. Many nations, including Bahrain, Iraq, and Lebanon, have these followers. Shia organisations formed and thrived in various countries, including Indonesia, as a result of the Islamic Republic of Iran's founding. Despite the existence of two other Shi'a factions in the modern age, namely Zaidiyah and Isma'iliyah, the Shia Imamiyah group is more established and has expanded to practically all Islamic nations, including the Western world, where Iran is active in hosting a cultural movement. ${ }^{20}$

Shia arrived in Indonesia at the same time as Islam. According to A. Hasjmy, the Islamic kingdom of Perlak was the archipelago's first Islamic kingdom, and its founder was a Shia. ${ }^{21}$ This kingdom was declared on 1 Muharram $225 \mathrm{H}^{22}$ However, there is little information regarding how Shia will evolve in the future. Nonetheless, multiple studies demonstrate that Shia influence in the archipelago may be found in the island's customs and traditions. BustamamAhmad demonstrates that Shia elements may be found in Aceh's political and cultural history, and that Shia and Persia have both influenced Aceh's identity development. ${ }^{23}$ In rather in depth, Iqbal investigates and reveals the true impact of Persia, including Shiite theology and tradition, on Indonesian Islamic culture. ${ }^{24}$ Although foreign cultures and traditions other than Shia and Persia have molded Moslem identity in Indonesia, such as India, it is apparent that the culture and traditions of Moslems in the Archipelago are more or less inspired by Shia and Persian Islam. ${ }^{25}$ 
Shia has evolved into a minority community in Indonesia, and this group has sparked debate. The Fatwa Commission of the Indonesian Moslem Scholar Council (MUI) once advised Moslems in Indonesia to be careful of Shia Muslims. ${ }^{26}$ The appeal decided at the MUI national work meeting in 1984 was:

Given the major differences between Shia and Ahlus Sunnah wal Jamâ‘ah, particularly those concerning "Imamat" (government), the Indonesian Moslem Scholar Council has appealed to Indonesian Moslems who understand Ahlus Sunnah wal Jamâ'ah to raise awareness of the possibility of Shia-based ideology being incorporated.

The Shia is not described as a cult in the Central MUI. This decision varies with the MUI verdict in East Java in 2012, which said that the Shia were a heretical and deceptive school, as follows:

(1) To confirm and verify the regional MUI's determination that Shia teachings (particularly Imamiyah Itsna Asy'ariyah or those who use the pseudonym Madzhab Ahlul Bait and so ond) and teachings that are similar to Shia Imamiyah Itsna Asyariyah teachings are erroneous and deceptive. (2) Declaring that using the word Ahlul Bait to refer to Shiites constitutes piracy against the Prophet Muhammad's Ahlul Bait (family).

A book titled "Getting to Know and Be Wary of Shia Irregularities in Indonesia" is also published by the Central MUI. Other ways of rejecting Shia include hosting seminars and publishing books and essays. Indeed, it was created on April 20, 2014, by the Anti-Shia National Alliance (ANNAS), whose aim is to save the religion from the Shia faith and to foresee the Shia movement in Indonesia. Some community organization do not dispute the existence of Shi' ites such as Nahdlatul Ulama ${ }^{27}$ and Al Jam'iyatul Washliyah. ${ }^{28}$ Interestingly, 
despite the fact that there are several anti-Shia initiatives in Indonesia, ${ }^{29}$ Shia understandings and actions remain unaffected by the Sunni majority. The Shia organization has been somewhat effective in propagating its ideology in Indonesia, especially following the fall of the New Order, by creating educational institutions that are guaranteed by law.

\section{Typology of Shia Education Institutions}

The birth and expansion of educational institutions founded by Shia groups in Indonesia aided the propagation of Shia doctrine. The education and learning program, according to Coombs and Ahmed, is divided into three categories. ${ }^{30}$ Institutionalized and hierarchical education, extending from primary schools to universities. Non-formal learning groups, which are organized and systematic educational activities that are held outside the formal education system and are aimed at specific subgroups of all ages and informal learning, namely lifelong learning that is not organized and often not systematic in which everyone gains knowledge, attitudes, skills, attitudes and insight about the environment for example in the family (home) environment. Shia minority groups in Indonesia arrange education for the benefit of their purpose by studying formally, informally, and informally based on the aforementioned classification.

In terms of education, the family is the first educational setting that children encounter as pupils, with parents acting as educators. In Indonesia, Shia organizations have grown into a distinct society with three million adherents. The presence of this group is manifested in two ways: by descent, in which a Moslem becomes a Shiite because his parents are Shiites, and through assimilation, in which a Moslem becomes a Shiite

because his parents are Shiites. As a result, he was born as a 
Shiite. Second, there is a non-hereditary way in which a Moslem does not become a Shiite by birth. During the quest, he assumed the name Shia. He eventually chose to become a Shia after learning and understanding the Shia beliefs. Despite their differences, they have come together to form a huge family.

In Indonesia, Shia communities use the home as the first educational institution, with husbands and wives teaching their children about religion. Marriage brings together a Shia family. According to the research, a Shia guy married a Sunni lady, and his wife subsequently converted to Shia, or vice versa. In certain circumstances, Shiites marry Shiites as well. They started a family after getting married. As parents, husband and wife perform the job of educators for their children. They are their children's teachers. Their children are educated according to Shia principles. They teach their children the fundamentals of Shi'a beliefs and include them in religious activities with Shia nuances. Shiite families have succeeded in establishing a bastion for the preservation and growth of Shi'a schools in Indonesia, despite their tiny numbers.

Shia doctrines are taught and promoted through non-formal educational institutions formed by this community, in addition to the home context. Non-formal educational institutions, as indicated by Coombs and Ahmed, carry out structured and systematic educational activities outside of the regular education system. ${ }^{31}$ Education is frequently held in the community and non-formal educational institutions such as institutions, discussion groups, taklim assemblies, and organizations, according to educational experts. Shia groups in Indonesia engage in non-formal education by forming organizations on a national and local levels, and then holding different educational events like as seminars, discussions, training, and recitation through these organizations. 
Since the demise of the New Order dictatorship, the operations of the group they created have become more open. Several Shiaaffiliated groups, such as the Indonesian Jamaah Ahlul Bait (IJABI), the Ahlul Bait Indonesia Youth Association (IPABI), Ahlul Bait Indonesia (ABI), and even hundreds of Islamic foundations, have sprouted up. Because the names of Imams and Shia academics are used as the foundation's name, Islamic foundations founded by Shia parties are particularly easy to recall. As a result of open religious activities, a number of groups representing the majority of Sunnis oppose the Shia community's activities in Indonesia, and some specialized organizations, such as the Anti-Shia National Alliance (ANNAS), have been formed to deny Shiites' existence in Indonesia. The Shiite group, on the other hand, continues to undertake events to educate its members and the general public about the Imamiyah Shia's beliefs.

The Shiite community in Indonesia not only organizes informal and informal educational and learning activities, but also forms and develops a formal education system. They have developed educational institutions at the secondary and even post-secondary levels. As formal educational institutions, they established educational institutions that follow a hierarchical, methodical, and organized learning process and relate to specific curriculum. Shia educational institutes may readily be found in Indonesia's major cities, particularly in Java. Educational institutions that are founded are subject to the national education system, particularly the Indonesian government's secondary and higher education legislation and policies. Despite the fact that Indonesia is not an Islamic country and that the majority of the population is Sunni, the Shia community is allowed to build educational institutions. The government has entirely abolished freedom so that Indonesians, regardless of religion or school, can establish 
and organize educational institutions and receive education in line with their religious and philosophical views.

\section{Non-Formal Educational Institutions: Islamic Organizations and Foundations}

The followers of Ahlul Bait or Shia groups in Indonesia established a number of national-scale organizations, including the Association of Indonesian Ahlul Bait Jamaah (IJABI), the Ahlul Bait Indonesia Youth Association (IPABI), and Ahlul Bait Indonesia, with the goal of instilling knowledge, attitudes, skills, and insights about Shia teachings and movements. They also founded a number of Islamic foundations on the Indonesian islands of Sumatra, Java, Kalimantan, Sulawesi, Bali, and West Nusa Tenggara. Shi' ite Islamic groups and foundations organize national conventions to foster camaraderie, organizational consolidation, and the formation of work projects. It's clear from the work programs that the organizations and foundations they founded were focused on educational and religious activities.

The Association of Indonesian Jamaah Ahlul Bait, abbreviated as IJABI, is one of the national scope Shia organizations in Indonesia. ${ }^{32}$ This group was created in the reformation era, namely on July 1, 2000, in Gedung Asia Afrika in Bandung, West Java, by Jalaluddin Rakhmat or Kang Jalal, among others. Kang Jalal, the founder of IJABI, was raised in the Sunni faith but converted to Shiism after receiving no formal religious education in the Shiite tradition. IJABI is a platform for Shiite groups to preserve and grow Shiite schools in Indonesia, despite being established on Pancasila basis. ${ }^{33}$ This organization is built on five pillars: rational and spiritual, non-sectarian, and prioritizes fiqh (Islamic law) values, pluralism, culture, and supporting the vulnerable. IJABI is an Islamic organization that aims to educate 
the weak and enlighten Sunni and Shia groups' thinking and knowledge of Shia. As a result, this organization is deeply engaged in the subject of education..

IJABI is a non-profit organization dedicated to emancipation and enlightenment. various ideas that attacked Ahlul Bait, providing a vehicle for critical study of Islamic sciences, establishing educational institutions, and conducting research and studies on Islamic teachings and society, this organization's vision is to "display an intellectual movement that enlightens Islamic thought and advocates against the weak." As a result, IJABI is involved in the field of education and learning. ${ }^{34}$ As a result, IJABI officials frequently undertake Islamic research and conversations in a variety of subjects, particularly Sunni-Shia engagement. IJABI also built schools for the poor, particularly in Cicalengka, Bandung, Cianjur, Bondowoso, Lumajang, and Makassar, by not quoting fees for students. Shia and Sunni communities acquired knowledge through IJABI activities, particularly in regards to Shia doctrines.

Ahlul Bait Indonesia, abbreviated ABI, is another organization that was later founded by a Shia faction in Indonesia. On Wednesday, June 15, 2011, this group was established in the Marine Hall in Cilandar, Jakarta. In truth, ABI was founded at the Ahlul Bait Indonesia national hospitality event on July 2425,2010 , when a group of nine people came together to start the ABI organization. Hassan Alaydrus, the General Chair of ABI, Ahmad Hidayat, the General Secretary, and Umar Shahab, the Syuro (Consultation) Council, are the two key leaders. Iranian alumni make up a large portion of the ABI board of directors. That is, they get official religious education in Iran, according to the Shia tradition. This group works on education, $d a^{6} w a h$ (Islamic preaching), and social issues. Training, seminars, book reviews, mass circumcision, observance of Islamic festivals, libraries, 
and the establishment of madrasa diniyah (Islamic elementary school) and Quranic madrasas are among the activities carried out. ${ }^{35}$ The Shia community in Indonesia can learn about Shia doctrines and customs by participating in ABI events.

The Ahlul Bait Indonesian Youth Association, or IPABI, is an umbrella organization for Shia youth in Indonesia. In Indonesia, this group has had some success in teaching Shiite youth. This group is concern in education, da'wah, and social issues. IPABI organized a series of conversations, seminars, and training sessions to educate Shiite youth in Indonesia about Shia doctrines.

The three Shia organizations mentioned above are on a national level, however there are other Islamic foundations working in the domains of education, da'wah, and social issues throughout Indonesia's various regions. These numerous foundations hold various events in the field of education to teach Shiites and even Sunni groups about what Shias are and how they are frequently misunderstood by the Sunni community in Indonesia. Shiite organisations in Indonesia have built Islamic foundations around the country, including Sumatra, Java, Kalimantan, Sulawesi, Bali, and West Nusa Tenggara.

In addition to social and religious indoctrination, all of these Islamic foundations frequently organize religious and educational events. Religious events and prayer meetings (tasawasul and kumail) are frequently held by various Islamic foundations, as are commemorations of Islamic festivals, including Ashura. The Shiite community, as well as Sunnis, were present at this holy event. Of course, such activities may strengthen their bonds as brothers and serve as a vehicle for teaching young people about Shia principles and customs. These Shia Islamic foundations also organize conferences, talks, and training on a regular basis. Ordinary public seminars are organized where the 
foundation's management addresses the issue of Islamic unity, and the resource individuals for this activity are Shiites and Sunnis. This exercise is meant to give awareness and modify Sunni organizations' attitudes toward Shia and the Shia population.

Then, completely for free, many conversations and trainings were given, which opened up studies in the fields of faith and philosophy. Participants in the conversation and training come from both Sunni and Shia communities, and it's not unusual for some Sunni followers to convert to Shia after participating in this activity. One of Islamic foundations' goals in Indonesia is to build an Islamic library with hundreds of Shia academics who have been translated into Indonesian. The availability of this library appeals to Sunni organizations that wish to honestly learn about and comprehend the Shia school. Formal educational and publishing organizations have also been formed by several Shia foundations. The Shiite community's programs are always examined during the Ahlul Bait Indonesia National Gathering events, which have been organized on multiple occasions. All Shiite Islamic groups and foundations in Indonesia participate in this activity, which brings them together to share information, review work programs that have been completed, and plan future programs to aid in the introduction and expansion of Shiites in Indonesia.

\section{Formal Education Institutions: Schools, Islamic Boarding Schools and Colleges}

Shiite in Indonesia developed a formal educational institution to give birth to the group's successors who have knowledge, attitudes, skills, and insights regarding Shia. Even though they use these educational institutions as a means for the spread and growth of Shia school of thought in Indonesia, the created 
institutions get approval from the Indonesian government and follow the national education system. Schools, boarding schools, and universities were among the educational institutions they built.

The Mutahhari Foundation in Bandung, West Java, is one of Indonesia's most well-known Islamic foundations. Jalaluddin Rachmat, often known as Kang Jalal, is in charge of this Islamic institution. He became a legislative member of the Indonesian Democratic Party of Struggle (PDIP) in 2014, a party noted for its zeal in the fight for Indonesian democracy. In Indonesia, he is also the founder and organizer of IJABI. SMA (Senior High School) Plus Muthahhari Bandung, SMP (Junior High School) Plus Muthahhari in Cicalengka Bandung, SMP Bandung Bahtera, and Sekolah Cerdas Mutahhari (SCM) Bandung are the four official educational institutions managed by Kang Jalal's foundation. ${ }^{36}$ According to Anwar, SMA Plus Mutahhari does indeed provide its pupils the choice to pick a school of Islam, as its creator stated, but it is apparent that the religious rituals followed in this school are similar to those followed in the Shia Imamiyahschool of thought. These educational institutions' methods, features, and allusions are Shia. ${ }^{37}$

The Islamic Boarding School Foundation (YAPI), Bangil, Pasuruan, East Java, Indonesia, runs Islamic boarding schools established by the Shia community. This institution, which was formed on June 21, 1976, by Habib Husein al-Habsyi, operates boarding schools for men and women and is involved in education and da'wah. Its creator, al-Habsyi, was renowned as a Sunni scholar at first, but ultimately became a Shia major figure. Ali Ridho al-Habsyi and Ahmad Hidayat al-Habsyi, two of his offspring, were sent to Qom, Iran, to learn Shia traditions and are now Shia figures in Indonesia. Pondok Pesantren Putra is managed by YAPI, and it houses three educational institutions: 
SMP Plus, SMA Plus, and Madrasah Diniyah (Islamic elementary school). Later on, YAPI took over Pondok Pesantren Putri, which oversees three educational institutions: SMP al-Ma'hadul Islami, SMA al-Ma'hadul Islami, Madrasah Diniyah al-Ma'hadul Islami, and Hawzah Imam Sadiq. It's worth noting that YAPI Bangil hosted a diniyah (elementary level) program with the goal of allowing pupils to learn about religious topics. Mutawasit, Tsanawi, and Tamhidi are the three tiers of the curriculum. The work of Iranian intellectuals, such as that of Ayatollah Nashr Makarim Shirazi, is the most significant reference in Madrasah Diniyah. They look into religious texts based on Shia beliefs. ${ }^{38}$ The hawzah curriculum is for students who are exclusively interested in religion and Islamic studies as a speciality. This program is for students who do not choose to participate in the SMP/SMA program..$^{39}$ One of the hallmarks of Shia is the term hawzah, which refers to historic Shia educational institutions in Iran, and Imam Sadiq, which is the name of one of the imams in the Shia Imamiyah school. The establishment of a boarding school run by YAPI Bangil undoubtedly helps to the growth of the Shia community in Pasuruan, East Java, in terms of both size and quality.

The Shia community in Indonesia arranges higher education in addition to building formal secondary school facilities. Shia organisations have built at least two higher educational institutions, notably ICAS Jakarta and the Islamic Philosophy College (STFI) Sadra. The Islamic College for Advanced Studies, or ICAS, was founded in London, England, in 1996. ICAS then opened branches in a number of places, including Jakarta, Indonesia. ICAS was established in Indonesia in 2003. Dr. Ali Movaheddi, ICAS London representative, and Prof. Nurcholish Madjid signed a collaboration agreement on July 29, 2002, which was confirmed by the Indonesian Ministry of Religious Affairs. ICAS Jakarta 
collaborated with Paramadina University on educational initiatives. ICAS Jakarta has launched two master's degree programs, one in Islamic philosophy and the other in Islamic mysticism. The instructors come from both Shiites and Sunnis. Komaruddin Hidayat and Kaustar Azhari Noer, both Sunni, were among the ICAS lecturers. Khalid al-Walid, Haidar Baqir, Muhsin Labib, and Abdullah Beik are Shiite academics, whereas Khalid alWalid, Haidar Baqir, Muhsin Labib, and Abdullah Beik are Sunni lecturers. The majority of these Shia professors were raised in Iran and got their religious education there. In addition, ICAS Jakarta invited Iranian guest professors. ICAS Jakarta students are Indonesian students who study philosophy and Sufism in the Shia tradition and use books produced by Iranian masters to learn both areas.

The second, STFI Sadra, is Indonesia's first high school of Islamic philosophy, which opened on July 12, 2012. It is located in Jakarta. ${ }^{40}$ The organizer hosted an international symposium with the topic "The Role of Islamic Philosophy in Assembling Civilizations" at the inaugural event. The Jakarta Hikmat Al Mustafa Foundation is in charge of the campus. The term Sadra, which is related to the name of the campus, relates to Mulla Sadra, a famous Shia thinker in the 17th century AD, who founded the Hikmah al-Muta'aliyah school of Islamic thought. This school of Islamic philosophy is supported by Iranian Shia intellectuals. The Islamic Philosophy department, as well as the $\mathrm{Al}$ Qur'an and Tafsir (Al Qur'an interpretation) majors, were established at STFI Sadra. Then, in the topic of Islamic Philosophy, a master's program was established on this site. Dr. Kholid AlWalid, an expert in Islamic philosophy who studied it in Iran, oversees the university. The campus instructors included some Sunni educators as well as Qom grads from Iran. The library gathers works of Iranian Shia philosophers, and these works 
form a source of reading for students and lecturers, as the campus concentrates on the subjects of philosophy and the Al-Qur'an. According to the Shia school of thinking, student research is supposed to develop the treasures of Islamic philosophy and the Al-Qur'an. Sadra STFI also collaborates with a number of Indonesian Islamic universities. STFI Sadra succeeded in introducing, conserving, and passing on the traditions of Islamic philosophy and the study of the Al-Qur'an to the Shia school of thought in the archipelago seven years after its founding.

Sadra STFI has a publishing house, Sadra Press, in addition to being a professional educational institution. This publisher has engaged in two operations that are intertwined: translation and publication. So far, Sadra Press has produced works by Iranian Shia intellectuals in a variety of subjects, including logic, theology, philosophy, and Sufism, among others. These works were originally written in Arabic or Persian before being translated into Indonesian. The key to success in translating and releasing these publications is the involvement of alumni of Iranian universities who are fluent in Persian. The books published by Sadra Press are widely available in Indonesian bookstores and are purchased and read by everyone interested in learning more about Islamic ideas from the Shia perspective. The presence of Sadra Press is well known, and this publishing house has served as a vehicle for disseminating knowledge and ideas regarding Shia thinking to Indonesian intellectual circles.

\section{Conclusion}

The organization of education and learning, particularly the establishment of Islamic educational institutions founded by the Shia community, has spurred the expansion of Shia school of thought in Indonesia from the beginning to the 
present. Informal education and learning takes place in the context of the family. Shiite men and women establish a family structure before educating their children according to Shia school of thought standards. Parents in the home context educate their children according to the Shia school of thinking as educators for their kids. Even if the Shia school of thought is still fundamental, the parents educate their children information, skills, attitudes, and insights about it.

In addition, the Shia community formed Islamic charities and organizations. Some of them founded formal educational institutions, while others conducted educational activities such as training, recitation, seminars, book reviews, and social service. Shia organizations have also succeeded in establishing legitimate educational institutions in Indonesia, spanning from basic to higher education levels. Sadra Islamic Philosophy College is regarded as a model for Shia higher education in Indonesia. Indonesian legislation permits Shia organizations to create educational institutions as long as they do not contradict Pancasila (Indonesia's Five Principles) or the 1945 Constitution, and these institutions would be considered similarly to those founded by the dominant Sunni group. Indonesian education laws prohibit discriminatory practices, ensuring that every citizen and group of citizens has the opportunity to get an education or create educational institutions. Because every citizen is equal before the law, ethnic, religious, and school of thought distinctions are not barriers to obtaining or organizing education. This is a fundamental reason why Shia organizations may flourish in Indonesia, and the push to create educational institutions is crucial to their success in fostering mutual understanding and cooperations. 


\section{Reference}

Abidin, Ahmad Zainal, Imam Fuadi, Nur Kholis, and Thoriqul Aziz. "Conflictual and Peaceful Sunni-Shia Relations: Study on Various Factors of State Policy Formation in Sampang and Yogyakarta." ESENSIA: Jurnal IImu-Ilmu Ushuluddin 21, no. 2 (2020). https://doi.org/10.14421/esensia.v21i2.2243.

Agil Siradj, Said. "Menggaga224-249s Teologi Perdamaian SunnîShî‘ah Di Indonesia.” Teosofi: Jurnal Tasawuf Dan Pemikiran Islam 3, no. 2 (2013): 317-40. https://doi.org/10.15642/ teosofi.2013.3.2.317-340.

Ahlul Bait Indonesia. "Organisasi Ahlul Bait Indonesia Dideklarasikan," 2011. https://www.ahlulbaitindonesia.or.id/berita/index.php/ s13-berita/organisasi-ahlul-bait-indonesia-dideklarasikan/.

Amal, M. Khusna. "Anti-Shia Mass Mobilization in Indonesia's Democracy: Godly Alliance, Militant Groups and the Politics of Exclusion." Indonesian Journal of Islam and Muslim Societies 10, no. 1 (2020): 25-48. https://doi.org/10.18326/ ijims.v10i1.25-48.

Amir-Moezzi, Mohammad Ali. "The Twelver Shia in Modern Times. Religious Culture and Political History, LeidenBoston-Köln, Brill, Collection « Social, Economic and Political Studies of the Middle East and Asia ", Vol. 72, 2000, 395 P.” AbstractaIranica,2002. https://doi.org/10.4000/abstractairanica.35477.

An-Nahidl, Nunu Ahmad. "IJABI Dan Pendidikan Ahlul Bait: Studi Kasus Pada Yayasan Muthahhari Bandung.” EDUKASI: Jurnal Penelitian Pendidikan Agama Dan Keagamaan 12, no. 1 (2014). https://doi.org/10.32729/edukasi.v12i1.77.

Anwar, Syaiful. "Pembelajaran Terpadu Dalam Mengembangkan Nilai-Nilai Keagamaan Siswa: Studi Khusus Pada SMU (Plus) Muthahhari Bandung." Universitas Pendidikan Indonesia, 2013.

Bustamam-Ahmad, Kamaruzzaman. "From Power to Cultural Landscapes: Rewriting History of Shi'ah in Aceh." Journal 
of Indonesian Islam 11, no. 2 (2017). https://doi.org/10.15642/ JIIS.2017.11.2.509-530.

Coombs, P., and M. Ahmed. Attacking Rural Poverty. How Non-Formal Education Can Help. Baltimore: John Hopkins Press, 1974.

Griffiths, Arlo. "The Sanskrit Inscription of Sankara and Its Interpretation in the National History of Indonesia." Bijdragen Tot de Taal-, Land-En Volkenkunde, 2021. https://doi.org/ 10.1163/22134379-bja10014.

Haghighat bin, Mehdi, Mojtaba Ansari, and Mohammadreza Bemanian. "A Study of Shia Teachings in Safavid Garden Cities." Journal of Studies On Iranian-Islamic City, no. 14 (2014): 5-12.

Hasim, Moh. "Syiah: Sejarah Timbul Dan Perkembangannya Di Indonesia.” Analisa 19, no. 2 (2012): 147-58.

Hasjmy, A. "Adakah Kerajaan Islam Perlak Negara Islam Pertama Di Asia Tenggara." In Sejarah Masuk Dan Berkembangnya Islam Di Indonesia. Jakarta: Al Ma’arif, 1983.

Hiro, Dilip. Iran under the Ayatollahs. 2013. https://doi.org/ 10.4324/9780203695456.

Hyman, Anthony. "An Introduction to Shi'i Islam: The History and Doctrines of Twelver Shi' ism." International Affairs, 1986. https://doi.org/10.2307/2618428.

Ida, Achmah. "Cyberspace and Sectarianism in Indonesia: The Rise of Shia Media and Anti-Shia Online Movements." Jurnal Komunikasi Islam 2, no. 2 (2016).

Ida, Rachmah, and Muhammad Saud. "The Narratives of Shia Madurese Displaced Women on Their Religious Identity and Gender Citizenship: A Study of Women and Shi'as in Indonesia." Journal of Religion and Health 60, no. 3 (2021). https://doi.org/10.1007/s10943-020-01001-y.

IJABI. “Tentang Kami,” n.d. 
Iqbal, Muhammad, and Ja'far Ja'far. "Contemporaru Development of Qur'anic Exegesis in Indonesia and Iran.” Journal of Contemporary Islam and Muslim Societies 3, no. 1 (2019). https://doi.org/10.30821/jcims.v3i1.4144.

Iqbal, Muhammad Zafar. Kafilah Budaya: Pengaruh Persia Terhadap Kebudayaan Indonesia. Jakarta: Citra, 2006.

Iryana, Wahyu, Nina Herlina Lubis, and Kunto Sofianto. "The Existence of Shia in Indonesia Between Tradition.” Paramita: Historical Studies Journal 28, no. 2 (2018): 125-36.

—. "The Existence of Shia in Indonesia Between Tradition." Paramita: Historical Studies Journal 28, no. 2 (2018).

Isya', Muhammad Andi “Pendidikan Dan Konflik (Potret Konflik Sunni-Syiah Dan Imbasnya Terhadap Pendidikan Di Bangil Kabupaten Pasuruan)." Progressa:Journal of Islamic Religious Instruction2, no. 1(2018). https://doi.org/10.32616/pgr.v2.1.104.1314.

Ja'far, Ja'far. "Respons Dewan Fatwa Al Jam'iyatul Washliyah Terhadap Isu Akidah Dan Syariah Di Era Global.” Al-Manahij: Jurnal Kajian Hukum Islam 10, no. 1 (2016): 97-118. https:/ /doi.org/10.24090/mnh.v10i1.919.

Ja'far Ja'far. "Al Jam'iyatul Washliyah Dan Pelestarian Akidah Ahl Sunnah Wa Al-Jama'ah Di Indonesia." Islamica: Jurnal Studi Keislaman 14, no. 1 (2019): 54-81. https://doi.org/ 10.15642/islamica.2019.14.1.54-81.

Madelung, W. "Review: The Twelver Shia in Modern Times: Religious Culture and Political History: The Twelver Shia in Modern Times: Religious Culture and Political History." Journal of Islamic Studies, 2002. https://doi.org/10.1093/ jis/13.2.207.

Makhsum, Ali. "Stigmatisasi Dan Ppropaganda Anti-Syiah: Sorotan Deskriptif Gerakan ANNAS." Jurnal CMES 12, no. 2 (2019): 182-91. https://doi.org/10.20961/cmes.12.2.37894. 
Makin, Al. "Homogenizing Indonesian Islam: Persecution of the Shia Group in Yogyakarta." Studia Islamika 24, no. 1 (2017). https://doi.org/10.15408/sdi.v24i1.3354.

Miles, Matthew B., and A. Michael Hubermen. "Qualitative Data Analisis." CEUR Workshop Proceedings, 1994.

Moore, Addison W. "Democracy and Education. John Dewey." The International Journal of Ethics, 1916. https://doi.org/ 10.1086/intejethi.26.4.2376473.

Mudzhar, Mohamad Atho. "Fatwa's' of the Council of Indonesian Ulama: A Study of Islamic Legal Thought in Indonesia, 1975-1988." ProQuest Dissertations and Theses, 1990.

Namazi, Rasoul. "Ayatollah Khomeini: From Islamic Government to Sovereign State." Iranian Studies 52, no. 1-2 (2019): 111-31. https://doi.org/10.1080/00210862.2018.1551054.

Rahman, Kholilul. "Syiah di Pekalongan: Studi atas Tradisi Syiah Pondok Pesantren Al Hadi Pekalongan Jawa Tengah." Religi:Jurnal Studi Agama-Agama 16, no. 1 (2020). https:/ /doi.org/10.14421/rejusta.2020.1601-06.

Rokhmad, Abu. "The Sunni-Shia Conflict in Madura Indonesia: Judging Individual Faith as Blasphemy.” Pertanika Journal of Social Sciences and Humanities 27, no. 2 (2019).

Rothman, Norman C. Global Shia: A Contemporary Perspective. Global Shia: A Contemporary Perspective, 2018.

Saefudin, Ahmad, and Fathur Rohman. "Building Social Harmony in the Jepara Shi' ite Minorities." Journal of Contemporary Islam and Muslim Societies 3, no. 2 (2019). https://doi.org/ 10.30821/jcims.v3i2.5622.

Sirry, Mun'im. "Fatwas and Their Controversy: The Case of the Council of Indonesian Ulama (MUI)." Journal of Southeast Asian Studies 44, no. 1 (2013). https://doi.org/10.1017/ S0022463412000641. 
Sofjan, Dicky. "Minoritization \& Criminalization of Shia Islam in Indonesia." Journal of South Asian and Middle Eastern Studies 39, no. 2 (2016). https://doi.org/10.1353/jsa.2016.0002.

STFI Sadra. "STFI Sadra Merupakan Sekolah Filsafat Islam Pertama Di Indonesia," n.d. http://sadra.ac.id/hello-world-2.html/.

Syarif, Dede, Iskandar Zulkarnain, and Dicky Sofjan. "Anti Shi' ism in Indonesia: Genealogy, Development, and Methods." Harmoni 16, no. 1 (2017): 24-37. https://doi.org/10.32488/ harmoni.v16i1.54.

Syahnan, Mhd., and Ja'far, Ja'far. “Examining Religious Moderation of the Al-Jam'iyatul Washliyah Fatwa Council." Journal of Indonesian Islam 15, no. 1 (2021). http://dx.doi.org/10.15642/ JIIS.2021.15.1.21-46.

Wahid, Ramli Abdul. "Aliran Minoritas Dalam Islam Di Indonesia." Journal of Contemporary Islam and Muslim Societies 1, no. 2 (2018). https://doi.org/10.30821/jcims.v1i2.1071.

YAPI Bangil. "Hauzah Imam Shadiq As," n.d. https:/yapibangil.org/ hauzah-imam-shadiq-as/.

Zulkifli, Zulkifli. "The Struggle of the Shi' is in Indonesia." Leiden University, 2009. 


\section{Endnotes:}

${ }^{1}$ Wahyu Iryana, Nina Herlina Lubis, and Kunto Sofianto, "The Existence of Shia in Indonesia Between Tradition,” Paramita: Historical Studies Journal 28, no. 2 (2018): 125-36.

${ }^{2}$ Mun'im Sirry, "Fatwas and Their Controversy: The Case of the Council of Indonesian Ulama (MUI)," Journal of Southeast Asian Studies, 2013, https://doi.org/ 10.1017/S0022463412000641; Mohamad Atho Mudzhar, "Fatwa's' of the Council of Indonesian Ulama: A Study of Islamic Legal Thought in Indonesia, 1975-1988," ProQuest Dissertations and Theses (1990).

${ }^{3}$ M. Khusna Amal, "Anti-Shia Mass Mobilization in Indonesia's Democracy: Godly Alliance, Militant Groups and the Politics of Exclusion," Indonesian Journal of Islam and Muslim Societies 10, no. 1 (2020): 25-48, https://doi.org/10.18326/ ijims.v10i1.25-48.

${ }^{4}$ Addison W. Moore, " Democracy and Education. John Dewey,” The International Journal of Ethics, 1916, https://doi.org/10.1086/intejethi.26.4.2376473.

${ }^{5}$ Kholilul Rahman, "Syiah di Pekalongan: Studi atas Tradisi Syiah Pondok Pesantren Al Hadi Pekalongan Jawa Tengah,” Religi: Jurnal Studi Agama-Agama 16, no. 1 (2020), https://doi.org/10.14421/rejusta.2020.1601-06.

${ }^{6}$ Muhammad Andi Isya', "Pendidikan Dan Konflik (Potret Konflik SunniSyiah Dan Imbasnya Terhadap Pendidikan Di Bangil Kabupaten Pasuruan)," Progressa: Journal of Islamic Religious Instruction 2, no. 1 (2018), https://doi.org/10.32616/ pgr.v2.1.104.13-14.

${ }^{7}$ Muhammad Asrori, "Konstruksi Nilai-Nilai Pendidikan Islam Multikultural Pada Komunitas Syiah Sampang Di Jemundo Sidoarjo, http://repository.unisma.ac.id/ handle/123456789/2078, 2021.

${ }^{8}$ Muhammad Iqbal and Ja'far Ja'far, “Contemporary Development of Qur'anic Exegesis in Indonesia and Iran," Journal of Contemporary Islam and Muslim Societies 3, no. 1 (2019), https://doi.org/10.30821/jcims.v3i1.4144.

9 Abu Rokhmad, "The Sunni-Shia Conflict in Madura Indonesia: Judging Individual Faith as Blasphemy,” Pertanika Journal of Social Sciences and Humanities 27, no. 2 (2019).

${ }^{10}$ Dicky Sofjan, "Minoritization \& Criminalization of Shia Islam in Indonesia," Journal of South Asian and Middle Eastern Studies 39, no. 2 (2016), https://doi.org/ 10.1353/jsa.2016.0002.

${ }^{11}$ Wahyu Iryana, Nina Herlina Lubis, and Kunto Sofianto, "The Existence of Shia in Indonesia Between Tradition,” Paramita: Historical Studies Journal 28, no. 2 (2018).

${ }^{12}$ Rachmah Ida and Muhammad Saud, "The Narratives of Shia Madurese Displaced Women on Their Religious Identity and Gender Citizenship: A Study of Women and Shi' as in Indonesia," Journal of Religion and Health 60, no. 3 (2021), https://doi.org/10.1007/s10943-020-01001-y. 
${ }^{13}$ Ahmad Zainal Abidin et al., "Conflictual and Peaceful Sunni-Shia Relations: Study on Various Factors of State Policy Formation in Sampang and Yogyakarta," ESENSIA: Jurnal Ilmu-IImu Ushuluddin 21, no. 2 (2020), https://doi.org/10.14421/ esensia.v21i2.2243.

${ }^{14}$ Ahmad Saefudin and Fathur Rohman, "Building Social Harmony in the Jepara Shi'ite Minorities," Journal of Contemporary Islam and Muslim Societies 3, no. 2 (2019), https://doi.org/10.30821/jcims.v3i2.5622.

${ }^{15}$ Matthew B. Miles and A. Michael Hubermen, "Qualitative Data Analisis," CEUR Workshop Proceedings, 1994.

${ }^{16}$ Anthony Hyman, "An Introduction to Shi'i Islam: The History and Doctrines of Twelver Shi'ism," International Affairs, 1986, https://doi.org/10.2307/2618428.

${ }^{17}$ W. Madelung, "Review: The Twelver Shia in Modern Times: Religious Culture and Political History: The Twelver Shia in Modern Times: Religious Culture and Political History," Journal of Islamic Studies, 2002, https://doi.org/10.1093/jis/13.2.207; Mohammad Ali Amir-Moezzi, "The Twelver Shia in Modern Times. Religious Culture and Political History, Leiden-Boston-Köln, Brill, Collection "Social, Economic and Political Studies of the Middle East and Asia ", Vol. 72, 2000, 395 P.," Abstracta Iranica, 2002, https://doi.org/10.4000/abstractairanica.35477.

${ }^{18}$ Rasoul Namazi, “Ayatollah Khomeini: From Islamic Government to Sovereign State,” Iranian Studies52, no. 1-2 (2019): 111-31, https://doi.org/10.1080/00210862.2018.1551054.

${ }_{19}$ Dilip Hiro, Iran under the Ayatollahs, Iran under the Ayatollahs, 2013, https://doi.org/10.4324/9780203695456.

${ }^{20}$ Norman C. Rothman, Global Shia: A Contemporary Perspective, Global Shia: A Contemporary Perspective, 2018.

${ }^{21}$ A Hasjmy, "Adakah Kerajaan Islam Perlak Negara Islam Pertama Di Asia Tenggara," in Sejarah Masuk Dan Berkembangnya Islam Di Indonesia (Jakarta: Al Ma’arif, 1983).

${ }^{22}$ Zulkifli Zulkifli, "The Struggle of the Shi” is in Indonesia" (Leiden University, 2009).

${ }^{23}$ Kamaruzzaman Bustamam-Ahmad, "From Power to Cultural Landscapes: Rewriting History of Shi'ah in Aceh,” Journal of Indonesian Islam 11, no. 2 (2017), https://doi.org/10.15642/JIIS.2017.11.2.509-530.

${ }^{24}$ Muhammad Zafar Iqbal, Kafilah Budaya: Pengaruh Persia Terhadap Kebudayaan Indonesia (Jakarta: Citra, 2006).

${ }^{25}$ Arlo Griffiths, "The Sanskrit Inscription of Sankara and Its Interpretation in the National History of Indonesia," Bijdragen Tot de Taal-, Land-En Volkenkunde, 2021, https://doi.org/10.1163/22134379-bja10014.

${ }^{26}$ Ramli Abdul Wahid, “Aliran Minoritas Dalam Islam Di Indonesia,” Journal of Contemporary Islam and Muslim Societies 1, no. 2 (2018), https://doi.org/10.30821/ jcims.v1i2.1071.

${ }^{27}$ Said Agil Siradj, "Menggagas Teologi Perdamaian Sunnî-Shî‘ah Di Indonesia," Teosofi: Jurnal Tasawuf Dan Pemikiran Islam 3, no. 2 (2013): 317-40, https://doi.org/ 10.15642/teosofi.2013.3.2.317-340. 
${ }^{28}$ Ja'far Ja'far, “Respons Dewan Fatwa Al Jam'iyatul Washliyah Terhadap Isu Akidah Dan Syariah Di Era Global,” Al-Manahij: Jurnal Kajian Hukum Islam 10, no. 1 (2016): 97-118, https://doi.org/10.24090/mnh.v10i1.919, Ja'far Ja'far, Dewan Fatwa Al Jam'iyatul Washliyah: Sejarah dan Fatwa-fatwa (Medan: Perdana Publishing \& Dewan Fatwa Pengurus Besar Al Jam'iyatul Washliyah, 2020); Mhd. Syahnan and Ja'far Ja'far, "Examining Religious Moderation of the Al-Jam'iyatul Washliyah Fatwa Council," Journal of Indonesian Islam 15, no. 1 (2021), http://dx.doi.org/10.15642/ JIIS.2021.15.1.21-46; Ja’far Ja'far, “Al Jam iyatul Washliyah Dan Pelestarian Akidah Ahl Sunnah Wa Al-Jama'ah Di Indonesia,” Islamica: Jurnal Studi Keislaman 14, no. 1 (2019): 54-81, https://doi.org/10.15642/islamica.2019.14.1.54-81.

${ }^{29}$ Dede Syarif, Iskandar Zulkarnain, and Dicky Sofjan, "Anti Shi' ism in Indonesia: Genealogy, Development, and Methods," Harmoni 16, no. 1 (2017): 24-37, https:// doi.org/10.32488/harmoni.v16i1.54; Ali Makhsum, "Stigmatisasi Dan Ppropaganda Anti-Syiah: Sorotan Deskriptif Gerakan ANNAS,” Jurnal CMES 12, no. 2 (2019): 182-91, https://doi.org/10.20961/cmes.12.2.37894; Achmah Ida, "Cyberspace and Sectarianism in Indonesia: The Rise of Shia Media and Anti-Shia Online Movements," Jurnal Komunikasi Islam 2, no. 2 (2016).

${ }^{30}$ P. Coombs and M. Ahmed, Attacking Rural Poverty. How Non-Formal Education Can Help (Baltimore: John Hopkins Press, 1974).

${ }^{31}$ Coombs and Ahmed, Attacking Rural Poverty.

${ }^{32}$ Moh Hasim, "Syiah: Sejarah Timbul Dan Perkembangannya Di Indonesia," Analisa 19, no. 2 (2012): 147-58.

${ }^{33}$ Nunu Ahmad An-Nahidl, "IJABI Dan Pendidikan Ahlul Bait: Studi Kasus Pada Yayasan Muthahhari Bandung," EDUKASI: Jurnal Penelitian Pendidikan Agama Dan Keagamaan 12, no. 1 (2014), https://doi.org/10.32729/edukasi.v12i1.77.

${ }^{34}$ IJABI, “Tentang Kami," n.d.

${ }_{35}$ Ahlul Bait Indonesia, "Organisasi Ahlul Bait Indonesia Dideklarasikan," 2011, https://www.ahlulbaitindonesia.or.id/berita/index.php/s13-berita/organisasiahlul-bait-indonesia-dideklarasikan/.

${ }^{36}$ An-Nahidl, "IJABI Dan Pendidikan Ahlul Bait: Studi Kasus Pada Yayasan Muthahhari Bandung."

${ }^{37}$ Syaiful Anwar, "Pembelajaran Terpadu Dalam Mengembangkan Nilai-Nilai Keagamaan Siswa: Studi Khusus Pada SMU (Plus) Muthahhari Bandung” (Universitas Pendidikan Indonesia, 2013).

${ }^{38}$ Mehdi Haghighat bin, Mojtaba Ansari, and Mohammadreza Bemanian, "A Study of Shia Teachings in Safavid Garden Cities," Journal of Studies On IranianIslamic City, no. 14 (2014): 5-12.

${ }^{39}$ YAPI Bangil, "Hauzah Imam Shadiq As,” n.d., https://yapibangil.org/hauzahimam-shadiq-as/.

${ }^{40}$ STFI Sadra, "STFI Sadra Merupakan Sekolah Filsafat Islam Pertama Di Indonesia," n.d., http://sadra.ac.id/hello-world-2.html/. 